\title{
BRPKM
}

Buletin Riset Psikologi dan Kesehatan Mental

http://e-journal.unair.ac.id/index.php/BRPKM

e-ISSN: 2776-1851

ARTIKEL PENELITIAN

\section{Pengaruh Work Flexibility terhadap Job Insecurity pada Karyawan Terdampak Covid-19}

\author{
AHMAD FUAD KOIRUL ROZIKIN \& CHOLICHUL HADI* \\ Fakultas Psikologi Universitas Airlangga
}

\begin{abstract}
ABSTRAK
Penelitian ini bertujuan untuk menguji pengaruh work flexibility terhadap job insecurity pada karyawan yang terdampak pandemi Covid-19. Penelitian ini menggunakan salah satu tipe pendekatan kuantitatif dengan survei. Subjek pada penelitian ini adalah karyawan yang sedang terdampak pandemi, dengan kriteria sedang work from home. Total jumlah subjek pada penelitian ini adalah 92 orang. Hasil dari pada penelitian work flexibility memiliki korelasi negatif dengan job insecurity. Nilai korelasi $\mathrm{R}$ berdasarkan tabel di atas berada pada angka 0,500. Setelah melakukan pengambilan data dan menguji hipotesis, maka kesimpulan yang dapat simpulkan dari penulis adalah, variabel work flexibility dapat memprediksi variabel job insecurity pada karyawan yang terjadi pada masa pandemi.
\end{abstract}

Kata kunci: job insecurity, work flexibility, work from home

\section{ABSTRACT}

This study aims to examine the effect of work flexibility on job insecurity in employees by the Covid-19 pandemic. This study uses one type of quantitative approach, namely a survey. Subjects in this study were employees who were experiencing a pandemic, with the criteria of being working from home. The total number of subjects in this study was 92 people. The results of the research on job flexibility have a negative correlation with job insecurity. The correlation value of $\mathrm{R}$ based on the table above is at 0.500 . After collecting data and testing hypotheses, the conclusions that can be drawn from the author are, the work flexibility variable can predict the work insecurity variable for employees that occurs during the pandemic.

Keywords: job insecurity, work flexibility, work from home

Buletin Penelitian Psikologi dan Kesehatan Mental (BRPKM), 2021, Vol. 1(2), 1497-1504

*Alamat korespondensi: Fakultas Psikologi Universitas Airlangga, Kampus B Universitas Airlangga Jalan Airlangga 4-6 Surabaya 60286. Surel: cholichul.hadi@psikologi.unair.ac.id

Naskah ini merupakan naskah dengan akses terbuka dibawah ketentuan the Creative Common Attribution License (CC-BY-4.0) (http://creativecommons.org/licenses/by/4.0), sehingga penggunaan, distribusi, reproduksi dalam media apapun atas artikel ini tidak dibatasi, selama sumber aslinya disitir dengan baik. 


\section{PENDAHULUAN}

Pada akhir Desember 2019 dunia digemparkan dengan adanya penyebaran Coronavirus yang pertama kali terdeteksi di negara Tiongkok yang kemudian menyebar ke lebih 150 negara di seluruh dunia. Indonesia sendiri pada 2 Maret 2020 secara resmi mengumumkan di Istana Kepresidenan bahwa telah terdapat warga Indonesia yang tertular virus tersebut. melihat perkembangan penyebaran virus yang sangat pesat pada 15 Maret 2020 Presiden Joko Widodo mengeluarkan himbauan kepada seluruh instansi supaya baik negeri maupun swasta untuk menghindari kerumunan manusia.

Sebagai bentuk pencegahan meluasnya Covid-19 di masa pandemi Covid-19 pemerintah menghimbau masyarakat untuk melakukan social distancing apabila memungkinkan. Social distancing dilakukan kepada semua kegiatan, seperti kegiatan bekerja, sekolah, beribadah, dan lain sebagainya. Semua kegiatan yang melakukan banyak interaksi dihimbau untuk dilakukan di rumah saja. Dimana hal itu menyebabkan permintaan dan pemasukan yang merosot yang akhirnya menyebabkan perusahaan akan banyak mengalami kerugian.

Kerugian yang terjadi pada perusahaan tersebut akan berdampak PHK (pemutusan hubungan kerja) pada karyawan selain itu alasan efisiensi perusahaan juga menjadi penyebab terjadinya PHK yang terjadi saat ini yang dikarenakan keuangan perusahaan yang mulai menipis. Mengutip dari Detik News, menurut data dari KADIN Indonesia (Kamar Dagang dan Industri Indonesia) mencatat bahwa hingga awal bulan Oktober 2020 sudah 6,4 juta pekerja di PHK. Gelombang pemutusan kerja (PHK) di Indonesia selama masa PSBB pada akhir April 2020 menunjukkan 15,6 persen, dari 15,6 persen tersebut 1,8 persen mendapatkan pesangon saat PHK, namun 13,8 persen pekerja yang terkena PHK tidak mendapat pesangon (Ngadi dkk., 2020). Dalam penelitian tersebut dijelaskan jumlah 16,7 persen adalah laki-laki dan 14,7 persen adalah perempuan. Hasil tersebut menunjukkan bahwa korban PHK dari laki-laki dan perempuan yang hampir berimbang. Kemudian, menurut data penelitian dalam jurnal tersebut 10,5 persen buruh/karyawan/pegawai korban PHK pada kuartal kedua 2020 adalah disebabkan dari pandemi Covid-19. Tindakan PHK dapat dibenarkan dengan mengacu pasal 164 ayat 1 Undang-Undang Ketenagakerjaan Republik Indonesia Tahun 2003 tentang ketenagakerjaan yang menjelaskan dimana pengusaha dapat melakukan pemutusan hubungan kerja terhadap pekerja/buruh disebabkan dengan keadaan yang memaksa (force majeure). Kasus PHK yang banyak terjadi di Indonesia juga akan meningkatkan job insecurity pada karyawan perusahaan.

Menurut De Witte (2005) dalam Job insecurity dapat diartikan sebagai persepsi ancaman dan kekhawatiran yang terkait dengan keberlanjutan pekerjaan. Di dalam job insecurity terdapat perasaan tidak berdaya dalam mempertahankan keberlanjutan pekerjaan yang dimiliki seseorang. Kondisi seperti ini menyebabkan seseorang berada dalam dua status, yaitu status sebagai seorang pekerja aktif dan pengangguran. Hal ini disebabkan dengan ancaman bagi seseorang untuk menjadi pengangguran.

Ancaman PHK di tahun 2021 masih berkelanjutan, hal ini membuat tingkat job insecurity pada pekerja atau buruh makin meningkat dikutip dari merdeka.com Presiden KSPI (Konfederasi Serikat Pekerja Indonesia) memprediksi bahwa akan adanya ledakan PHK di tahun 2021.

Dalam kaitannya tersebut KSPI tidak meyakini pernyataan pemerintah yang menyatakan bahwa 2021 akan tercipta lapangan kerja baru dari hasil komitmen para investor luar negeri. Hal ini disebabkan karena yang terjadi adalah perpindahan dari karyawan yang di PHK untuk menjadi karyawan outsourcing atau pekerja kontrak. Terlebih terjadinya pandemi Covid-19 yang akan menurunkan produktivitas, sehingga akan berdampak pada produksi dan pertumbuhan ekonomi. 
Pada 5 November 2020 lalu, Badan Pusat Statistik telah resmi mengumumkan Indonesia tengah mengalami resesi. Dampak resesi tersebut mengakibatkan terjadinya PHK yang marak terjadi. Banyak perusahaan yang melakukan PHK pada pekerja/buruh. Perusahaan yang melakukan PHK pun beragam, mulai dari pabrik sepatu hingga perusahaan karaoke. Permasalahan Covid-19 memang sangat berimbas pada sektor ekonomi sehingga PHK sering terjadi.

Dalam hal ini terjadinya perubahan cara bekerja dalam masa pandemi adalah perubahan cara kerja yang awalnya mengharuskan untuk hadir yang kemudian berubah menjadi fleksibel. Dalam hal ini perubahan cara kerja tersebut akan membuat karyawan beradaptasi dengan lingkungan baru. Menurut Morgeson, dkk. (2015 dalam Tang dkk. 2021) teori sistem peristiwa menunjukkan sejauh mana suatu peristiwa bermakna dan berdampak. Berdasarkan teori tersebut pandemi Covid-19 adalah peristiwa yang berbeda dan baru yang sebelumnya belum pernah terjadi sehingga dalam penerapan sistem bekerja pada karyawan berubah karena belum ada prosedur dan pedoman yang jelas guna untuk mengarahkan perilaku karyawan. Terjadinya pandemi Covid-19 menyebabkan cara bekerja karyawan juga berubah, selain itu dalam penyelesaian pekerjaan mereka yang disebabkan perubahan sistem bekerja juga berbeda, hal tersebut kemudian akan membuat persepsi hambatan keberhasilan jangka panjang karyawan.

Dengan terus meluasnya virus pandemi yang sulit dikendalikan, pada 15 Maret 2020 Presiden Joko Widodo mengeluarkan himbauan kepada seluruh instansi supaya baik negeri maupun swasta untuk menghindari kerumunan manusia. Dimasa pandemi ini karyawan yang mengalami work flexibility setengah dari karyawan di AS bekerja dari rumah di masa pandemi saat ini (Kwong dkk., 2021). Kemudian di seluruh dunia terdapat 136 negara yang menerapkan sistem work flexibility di masa pandemi saat ini. Menurut International Labour Organization (ILO) memperkirakan terdapat 18 persen pekerja, memiliki pekerjaan yang sesuai untuk menerapkan work flexibility. Hal ini menyebabkan jutaan karyawan di seluruh dunia yang mulai bekerja dari luar tempat kerja melalui virtual dan tanpa tatap muka.

Menurut Ilgen dan Hollenbeck (1991 dalam Maretasari \& Ratmawati 2020) mendefinisikan otonomi sebagai sejauh mana pekerjaan menyediakan substansial kebebasan, kemerdekaan, dan kebijaksanaan pada individu dalam penjadwalan kerja, dan menentukan prosedur yang digunakan untuk melaksanakan pekerjaan. Dalam hal ini manajemen memberikan kebebasan kepada karyawan atau pekerja untuk bagaimana pekerjaan itu diselesaikan, bagaimana pekerjaan itu diselesaikan. Flexibility at work adalah dukungan dari manajemen dan perhatian yang diberikan kepada karyawan atau pekerja untuk menekan angka penyebaran Covid-19 di perusahaan atau organisasi.

Penerapan work flexibility pada perusahaan dinilai menguntungkan untuk perusahaan, penerapan work flexibility dapat meningkatkan produktivitas dalam bekerja dan meningkatkan kualitas pekerjaan, kemudian menekan tingkat ketidakhadiran dan keterlambatan pegawai, meningkatan masa kerja pekerja terutama pekerja dengan berkualitas, dan perusahaan dapat menambah pekerja tanpa menambah luasan kantor.

Perubahan yang terjadi pada karyawan ketika bekerja dengan sistem work flexibility adalah adanya keterbatasan komunikasi. Sistem kerja dengan dimasa pandemi ini menyebabkan karyawan tidak bertemu dengan atasan dan rekan kerja secara langsung (Smyth dkk., 2021). Menurut Smithson \& Lewis (2000) ketidakamanan kerja didefinisikan sebagai perasaan tidak aman (kondisi psikologis) yang dirasakan karyawan karena terhadap perubahan lingkungan kerja. Lingkungan kerja memiliki andil 
dalam faktor job insecurity. Perubahan lingkungan tersebut meliputi lingkungan fisik dan non fisik. Perubahan tersebut berasal dari lingkungan kerja yang pada awalnya karyawan bekerja di kantor yang kemudian setelah pandemi terjadi karyawan bekerja secara fleksibel diluar kantor (Darmawan, 2020; Lee, 2020; Setiawan \& Putra, 2016).

Kemudian dilihat dari faktor kontrak kerja dalam penelitian yang dilakukan pekerja dengan kontrak tidak tetap adalah pekerja yang memiliki tingkat ketidakyakinan akan kelanjutan pekerjaannya di masa depan dari pada pegawai tetap. Dari penjabaran diatas peneliti tertarik meneliti apakah pekerja yang sedang melakukan atau work flexibility mengalami job insecurity terhadap pekerjaan.

\section{Desain Penelitian}

\section{METODE}

Metode penelitian yang digunakan oleh peneliti dalam penelitian ini adalah menggunakan pendekatan kuantitatif. Pada penelitian ini subjek akan diminta untuk memberikan jawabannya dengan menggunakan instrumen atau alat ukur yang nantinya jawaban itu akan dijadikan dalam bentuk data statistik dan selanjutnya akan dilakukan uji hipotesis. Jelaskan desain penelitian yang digunakan (survei cross-sectional atau observasional atau eksperimental atau kualitatif-fenomenologi atau kualitatif-studi kasus, dsb.). Penulis juga diharapkan menguraikan justifikasi pemilihan desain penelitian dengan menyesuaikannya dengan tujuan/hipotesis/pertanyaan penelitian.

\section{Partisipan}

Partisipan dalam penelitian ini adalah karyawan dalam suatu perusahaan di Indonesia yang yang terdampak oleh pandemi Covid-19 dan sedang melakukan atau pernah melakukan work from home. Setelah melakukan proses pengumpulan data berdasarkan kriteria dan didapatkan 107 partisipan karyawan, namun dalam analisisnya 15 partisipan memiliki skor yang ekstrim sehingga harus dieliminasi yang kemudian populasi penelitian tersisa 92. Yang terdiri dari 64 partisipan berusia 20-25 tahun, 10 partisipan yang berusia 26-30 tahun, 5 partisipan yang berusia 31-35 tahun, 2 partisipan yang berusia 41-45 tahun dan 7 partisipan yang berusia lebih dari 46 tahun. Jika digolongkan menurut tingkat pendidikan maka partisipan penelitian ini memiliki 19 partisipan yang berpendidikan SMA dan 73 partisipan yang telah menempuh perguruan tinggi.

\section{Pengukuran}

Skala yang digunakan pada variabel job insecurity adalah skala Job Insecurity Scale (JIS) dari De Witte (2005). Alat ukur ini memiliki 1 dimensi yang terdiri dari 4 item penelitian dengan 3 item favorable dan 1 item unfavorable. Dalam skoring untuk item unfavorable apabila responden memiliki sifat negatif dalam skoring akan diberikan skor positif.

Skala yang digunakan dalam mengukur work flexibility adalah skala dari Porter \& Ayman (2010). Ada 5 indikator yang digunakan dalam alat ukur Porter \& Ayman (2010) antara lain: perusahaan memberikan kemudahan untuk dapat menentukan jam kerja, karyawan diberikan kebebasan dalam metode penyelesaian pekerjaannya, karyawan diberikan kebebasan dalam menentukan schedule kerjanya, karyawan telah cukup memiliki fleksibilitas dalam menentukan lokasi/tempat melaksanakan tugas/pekerjaan, karyawan diberikan kebebasan untuk menentukan prioritas dalam pekerjaannya. 
Reliabilitas masing masing alat ukur yang digunakan dalam penelitian ini adalah 0,959 untuk variabel Job Insecurity Scale (JIS), sedangkan pada alat ukur Work Flexibility Scale adalah 0,86, kemudian pada alat ukur work from home adalah 0.80 .

\section{Analisis Data}

Dalam penelitian ini, peneliti analisis statistik dalam mengolah data. Dalam penelitian ini penulis menggunakan teknik analisa data regresi dengan bantuan aplikasi SPSS 25.0 for Windows. Alasan penulis menggunakan analisa secara regresi adalah karena tujuan penelitian ini adalah untuk mengetahui pengaruh variabel X (work flexibilty) terhadap variabel Y (job insecurity).

\section{HASIL PENELITIAN}

Hasil analisis statistik deskriptif pada penelitian ini meliputi perhitungan rata-rata (mean), Median, rentang populasi (range), standar deviasi, nilai maksimum, dan nilai minimum. Berikut merupakan hasil analisis deskriptif terhadap data yang diperoleh adalah work flexibility memiliki nilai rata-rata 14,68 dengan nilai minimum sebesar 5 dan maksimal adalah 25, kemudian pada range sebesar 20. Selanjutnya job insecurity memiliki rata-rata 14,16, nilai minimum 9 nilai maksimal 10 dan range 11 . Hasil dari uji asumsi dari penelitian ini didapatkan bahwa persebaran data dalam penelitian ini normal, deviation from linearity dari skala work flexibility dan job insecurity mendapatkan hasil 0,423 yang berarti kedua variabel memiliki hubungan yang linear, scatterplot tidak membentuk suatu pola tertentu sehingga dapat disimpulkan bahwa data lolos uji heteroskedastisitas.

Dari uji korelasi dapat dilihat bahwa work flexibility memiliki hubungan negatif terhadap job insecurity karena nilai signifikansi 0,000 dimana nilai tersebut $<0,05$. Sedangkan untuk kekuatan hubungan antara kedua variabel tersebut masuk dalam kategori sedang, dilihat dari nilai koefisien -0,482 yang berada pada rentang 0,500-1,00 dengan artian kekuatan hubungan yaitu kuat. Dalam uji korelasi ini dapat disimpulkan bahwa terdapat hubungan negatif di tingkat sedang antara variabel work flexibility dengan job insecurity. Hal ini berarti nilai work flexibility naik, maka nilai job insecurity turun, begitu juga sebaliknya. Berdasarkan uji regresi maka didapatkan nilai korelasi R berdasarkan tabel di atas berada pada angka 0,482. Pada nilai $R$, rentang nilai berkisar antara 0 hingga 1 . Semakin nilai mendekati angka 1 maka hubungan antar variabelsemakin kuat, sebaliknya apabila nilai R semakin mendekati 0 maka besar pengaruh semakin lemah. Dari tabel di atas menunjukkan bahwa nilai R sebesar 0,482 yang berarti cukup kuat. Lalu angka R Square menunjukkan koefisien sebesar 0,232 menyatakan bahwa besaran pengaruhvariabel work flexibility terhadap job insecurity sebesar $23 \%$, sisanya $77 \%$ di pengaruhi oleh variabel lain.

\section{DISKUSI}

Hasil dari pada penelitian work flexibility memiliki korelasi negatif dengan job insecurity. Nilai korelasi $\mathrm{R}$ berdasarkan tabel di atas berada pada angka 0,482 . Pada nilai $\mathrm{R}$, rentang nilai berkisar antara 0 hingga 1. Semakin nilai mendekati angka 1 maka hubungan antarvariabel semakin kuat, sebaliknya apabila nilai $\mathrm{R}$ semakin mendekati 0 maka besar pengaruh semakin lemah. Lalu angka R Square menunjukkan koefisien sebesar 0,232 menyatakan bahwabesaran pengaruh variabel work flexibility terhadap job insecurity sebesar 23\%, sisanya $77 \%$ dipengaruhi oleh variabel lain.

Dalam penelitian ini penyebab rendahnya job insecurity pada karyawan yang mengalami work flexibility

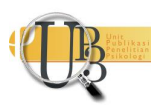


secara teori menurut Maretasari \& Ratmawati (2020), dalam penerapan work flexibility digunakan untuk mengamankan atau memproteksi karyawan. Disisi lain penerapan work flexibility sangat menguntungkan perusahaan (Maretasari \& Ratmawati, 2020)

Pada penelitian yang dilakukan Maretasari \& Ratmawati (2020) menunjukkanterdapat pengaruh negatif antara work flexibility dan kinerja pada karyawan. Sehingga semakintinggi tingkat work flexibility maka akan semakin rendah kinerja pada karyawan. Lu, dkk. (2008) berpendapat bahwa work flexibility dapat diwujudkan dengan jam kerja per hari yang lebih sedikit atau bekerja pada jumlah jam yang sama tetapi dengan fleksibilitas yang lebih besar. Work flexibility membawa perubahan di lingkungan kerja, dimana karyawan tidak perlu lama bekerjadalam jam yang sama dan atau sebanyak jam yang ditetapkan kantor. Dalam hal ini work flexibility di masa pandemi akan membawa perubahan lingkungan dalam organisasi.

Menurut Setiawan (2012 dalam Darmawan, 2020) faktor-faktor yang mempengaruhi job insecurity adalah karakteristik demografis, ketidakjelasan peran, kondisi lingkungan kerja, dan perbedaan individu yang meliputi locus of control dan nilai individu. Menurut Sedarmayati (2001 dalam Logahan dkk., 2013) lingkungan kerja adalah keseluruhan alat perkakas dan bahan yang dihadapi,lingkungan sekitarnya dimana seseorang bekerja, metode kerjanya, serta pengaturan kerjanya baik sebagai perseorangan maupun sebagai kelompok. Menurut Widha dkk. (2021) locus of control merupakan aspek kepribadian yang kontinum, sehingga setiap individu memiliki locus of control internal maupun eksternal, akan tetapi keduanya akan muncul salah satu dari locus of control yang paling kuat. Dalam penjelasan diatas terjadinya job insecurity dipengaruhi olehlingkungan kerja dan locus of control dalam diri seseorang. Dalam hal ini kebijakan pemerintahtentang larangan untuk bekerja dengan tatap muka yang akhirnya membentuk kebijakan work flexibility yang membuat lingkungan kerja dan locus of control para karyawan yang akhirnya mempengaruhi job insecurity.

\section{SIMPULAN}

Kemudian dapat disimpulkan bahwa dalam penelitian ini work flexibility dapat memprediksi job insecurity. Dimana pada masa pandemi Covid-19 work flexibility diprediksidapat mempengaruhi job insecurity, dimana semakin tinggi tingkat work flexibility maka job insecurity akan semakin rendah dan sebaliknya apabila work flexibility rendah maka job insecurity akan semakin tinggi.

\section{UCAPAN TERIMAKASIH}

Alhamdulillah, puji syukur kehadirat Allah SWT sebab atas berkat rahmat serta hidayahnya, penulis diberi kemudahan serta kelancaran dalam menuntaskan skripsi dengan judul "Pengaruh Work Flexibility terhadap Job Insecurity pada Karyawan Terdampak Covid-19" bagaikan salah satu prasyarat buat mendapatkan gelar Sarjana Psikologi Universitas Airlangga Surabaya. Penulis menyadari kalau skripsi ini tidak akan tuntas tanpa dorongan serta sokongan dari banyak pihak yang ikut andil dalam proses pengerjaannya. 


\section{DEKLARASI POTENSI TERJADINYA KONFLIK KEPENTINGAN}

Ahmad Fuad Koirul Rozikin dan Cholichul Hadi tidak bekerja, menjadi konsultan, memiliki sahan, atau menerima dana dari perusahaan atau organisasi manapun yang mungkin akan mengambil untung dari diterbitkannya naskah ini.

\section{PUSTAKA ACUAN}

Darmawan, F. (2020). Pengaruh Kohesivitas Kelompok dan Kesiapan Berubah Terhadap Job Insecurity Pada Supir Taksi Konvensional. Psikoborneo: Jurnal Ilmiah Psikologi, 8(1), 8-17. http://ejournals.unmul.ac.id/index.php/psikoneo/article/view/4852

De Witte, H. (2005). Job insecurity: Review of the international literature on definitions, prevalence, antecedents and consequences. SA Journal of Industrial Psychology, 31(4). https://doi.org/10.4102/sajip.v31i4.200

Kwong, A. S. F., Pearson, R. M., Adams, M. J., Northstone, K., Tilling, K., Smith, D., Fawns-Ritchie, C., Bould, H., Warne, N., Zammit, S., Gunnell, D. J., Moran, P. A., Micali, N., Reichenberg, A., Hickman, M., Rai, D., Haworth, S., Campbell, A., Altschul, D., ... Timpson, N. J. (2021). Mental health before and during the COVID-19 pandemic in two longitudinal UK population cohorts. The British Journal of Psychiatry, 218(6), 334-343. https://doi.org/10.1192/bjp.2020.242

Lee, S. A. (2020). Coronavirus Anxiety Scale: A brief mental health screener for COVID-19 related anxiety. Death Studies, 44(7), 393-401. https://doi.org/10.1080/07481187.2020.1748481

Logahan, J. M., \& Tjoe, T. F., \& Naga, N. (2013). Kompensasi Terhadap Kinerja Karyawan CV MUM INDONESIA Konsep Lingkungan Kerja , Kompensasi , dan Kinerja. Binus Business Review, 3(1), 573586. https://doi.org/10.21512/bbr.v3i1.1344

Lu, L., Kao, S. F., Chang, T. T., Wu, H. P., \& Cooper, C. L. (2008). Work/Family Demands, Work Flexibility, Work/Family Conflict, and Their Consequences at Work: A National Probability Sample in Taiwan. International Journal of Stress Management, 15(1), 1-21. https://doi.org/10.1037/10725245.15.1.1

Maretasari, R., \& Ratmawati, D. (2020). Pengaruh Work Demand Dan Work Flexibility Terhadap Kinerja Karyawan Pt. Mandiri Tunas Finance Dengan Organizational Commitment Sebagai Variabel Intervening. Jurnal Ekonomi Dan Bisnis Airlangga, 30(1), 65. https://doi.org/10.20473/jeba.v30i12020.65-80

Ngadi, N., Meliana, R., \& Purba, Y. A. (2020). Dampak Pandemi Covid-19 Terhadap Phk Dan Pendapatan Pekerja Di Indonesia. Jurnal Kependudukan Indonesia, 2902, 43. https://doi.org/10.14203/jki.v0i0.576

Porter, S., \& Ayman, R. (2010). Work flexibility as a mediator of the relationship between work-family conflict and intention to quit. Journal of Management and Organization, 16(3), 411-424. https://doi.org/10.5172/jmo.16.3.411

Setiawan, I., \& Putra, M. (2016). Pengaruh Job Insecurity Terhadap Kepuasan Kerja Dan Turnover

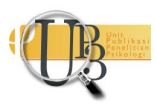


Intention Pada Karyawan Legian Village Hotel. E-Jurnal Manajemen Universitas Udayana, 5(8), 252971.

Smithson, J., \& Lewis, S. (2000). Is job insecurity changing the psychological contract? Personnel Review, 29(6), 680-702. https://doi.org/10.1108/00483480010296465

Smyth, C., Cortis, N., \& Powell, A. (2021). University staff and flexible work: inequalities, tensions and challenges. Journal of Higher Education Policy and Management, 43(5), 489-504. https://doi.org/10.1080/1360080X.2020.1857504

Tang, M. L., Li, Y. Q., Chen, X., Lin, H., Jiang, Z. C., Gu, D. L., Chen, X., Tang, C. X., \& Xie, Z. Q. (2021). Coinfection with common respiratory pathogens and sars-cov-2 in patients with covid-19 pneumonia and laboratory biochemistry findings: A retrospective cross-sectional study of 78 patients from a single center in China. Medical Science Monitor, 27, 1-8. https://doi.org/10.12659/MSM.929783

Widha, L., Rahmat, H. K., \& Basri, A. S. H. (2021). A Review of Mindfulness Therapy to Improve Psychological Well-being During the Covid-19 Pandemic. Proceeding of International Conference on Science and Engineering, 4, 383-386. 